\title{
Part-time Employment and Business Cycle in Central and Eastern Europe
}

\author{
Kamila Fialová ${ }^{1}$
}

\begin{abstract}
This article explores the development of part-time employment in Central and Eastern Europe and compares it to Western Europe. On the macro level it examines the role of the business cycle and its effect on part-time employment in the two groups of countries since 2001. The key result reveals that contrary to the West, the business cycle development exerts a significant negative effect on the part-time employment rate in Eastern Europe. When the economy operates below its potential, part-time employment tends to grow more than full-time employment. This finding is consistent with the labour demand effect and reflects the pursuit of flexibility by firms as well as the adjustment in composition of employment to changing economic conditions. The countercyclical effect is even stronger for involuntary part-time employment. Separate analyses of individual demographic groups of workers reveal a significant negative effect of the business cycle on part-time employment of older workers and male primeage workers in Eastern Europe. In contrast, the effect is insignificant for young workers and unclear for prime-age women.
\end{abstract}

Keywords: business cycle, part-time employment, working time

JEL classification: J08, J21, J22, O52

Received: 4 March 2017/ Accepted: 2 May 2017/ Sent for Publication: 8 June 2017

\section{Introduction}

Part-time (PT) employment represents a form of non-standard employment relationships that have been rapidly expanding in Europe during the last decades (for an overview see Eichhorst and Marx, 2015). The average share of part-timers on total employment in the European Union as a whole has been steadily increasing since late 1990s and hovered below $20 \%$ in 2013. Although it is a common phenomenon in Europe, large differences in patterns of PT employment exist between the countries of Central-Eastern and Western Europe. ${ }^{2}$ In 2013, PT employment was more widespread in Western Europe:

\footnotetext{
${ }^{1}$ Institute of Sociology of the Czech Academy of Sciences, Jilská 1, 11000 Praha 1, Czech Republic. E-mail address: kamila.fialova@soc.cas.cz.

${ }^{2}$ The group of Eastern European countries (East) covers those Central and Eastern European countries that joined the European Union in 2004 and after: Bulgaria, the Czech Republic, Estonia, Cyprus, Latvia, Lithuania, Hungary, Malta, Poland, Romania, Slovenia, Slovakia, and Croatia. The group of Western European countries (West) consists of Belgium, Denmark,
} 
the data showed an average share of $23.1 \%$ on total employment and an upward trend. In contrast, the average share of PT employment in Eastern Europe stood at $6.9 \%$ in 2013 and showed no clear trend.

Despite the significant differences between PT employment in Western and Eastern Europe, the situation in the latter has never been sufficiently covered by economic research. Eurofound (2011) explains the discrepancy in PT employment between the new and old member states by the prevailing employees' preferences of full-time work driven by low average hourly pay, common access to free childcare and low fertility rate; the low overall employment rates in the former are then put in connection with the high incidence of undeclared work. Fialová (2017) generally confirms this view and concludes that part-time employment in Western and Eastern Europe is driven by different factors. The author indicates that in the East, rigorous EPL limits the use of part-time contracts by firms and the development of the business cycle also has an adverse effect. In contrast, higher trade union density, greater share of temporary jobs and widespread shadow economy seem to have a positive effect. Other and more complex studies are still missing. In contrast, this phenomenon in Western Europe receives far more attention (see e.g. Buddelmeyer et al., 2008 and 2004, Smith et al., 1998, Mourre, 2006, Garibaldi and Murro, 2002, Booth and van Ours, 2010, Walvei, 1998). In our paper, we try to fill this literature gap.

From macroeconomic perspective, PT employment may bring about many positive consequences. It may represent a feasible alternative to economic inactivity for certain groups of people that are unwilling or unable to work full-time and in this sense it may boost the labour force participation and increase potential output and overall economic performance of the country. Moreover, this working arrangement might increase overall labour market flexibility through adjustment of hours worked and thus help to mitigate the fluctuating labour costs during the business cycle. In this sense, the possibility to work PT is equally important as the possibility to move from full-time work to PT and back again. However, here also resides the potential drawback of increasing PT employment on the macro level: while the expansion of PT employment may reduce the pool of inactive people, it may also grow in proportion at the expense of full-time employment and thus reduce overall labour utilisation. ${ }^{3}$

Also from the micro perspective, PT employment has its drawbacks. Employers may face higher fixed costs connected with PT employment (recruitment, training etc.). For employees, the negative aspects include mainly lower wages ${ }^{4}$ and fringe benefits, lower

Germany, Ireland, Greece, Spain, France, Italy, Luxembourg, the Netherlands, Austria, Portugal, Finland, Sweden, and the United Kingdom; we further add non-EU Norway, Switzerland and Iceland, which we classify as the Western European countries for the purposes of this paper to gain more data.

${ }^{3}$ In many countries with widespread part-time employment, flows out of part-time into full-time employment are rather rare and people tend to stay in their part-time jobs even after their original reasons thereto cease to exist (OECD, 2010).

${ }^{4}$ Lower wages may partly result from higher fixed costs of hiring a new worker, both full- and part-time, which, when distributed over fewer hours of work in case of part-time positions, reduce the hourly wage. For voluntary part-timers lower wages may reflect the compensating differential 
job security, hindered access to training and promotion, higher risk of poverty and worsened access to unemployment benefits and re-employment assistance (OECD, 1999). ${ }^{5}$ However, as the OECD (2010) shows, these disadvantages may be at least for certain groups of employees more than compensated by more family-friendly workingtime arrangements and better health and safety, which results in higher job satisfaction of PT employees. This mainly holds for women who choose PT voluntarily, and is not the case for other workers.

The decision to accept or offer PT work is a result of many factors of influence, the most important of which may be listed as follows (Smith et al., 1998; Delsen, 1998; or Buddelmeyer et al., 2008): Firstly, the business cycle development exerts a short- to medium-term effect on PT employment. Secondly, labour market institutional settings have a long-term effect on PT employment. The factors involved include: employment protection legislation, the tax system, trade unions, family and child benefits, and the unemployment benefit system. Thirdly, structural factors of economic, demographic, and social character have a long-term effect on PT employment. These are the share of employment in the service sector, the female labour force participation rate, the level of fertility, the schooling rate of young population, ageing of the population, the size of the shadow economy, etc.

The focus of this article is the role of the business cycle in the development of PT employment. ${ }^{6}$ Despite the importance of this issue, research on the behaviour of PT employment over the economic cycle is still rather scarce. Several exceptions are Buddelmeyer et al. (2008) or Partridge (2003), Blank (1990) and Ratti (1991) who examined the US data and revealed a countercyclical behaviour of the involuntary PT employment rate. Further, Kjeldstad and Nymoen (2012) revealed significantly different effects of economic fluctuations on underemployment between women and men in Norway. While underemployed women are predominantly permanently employed on part-time basis, men are usually expelled from their jobs on part-time basis only temporarily and their underemployment is more sensitive to economic fluctuations.

The economic development of the last two decades with the 2008-2009 economic recession offers us favourable conditions to explore the role of the business cycle in the PT employment development. In our research we try to reveal whether PT employment has served as a flexibility device for firms during economic hardship in Eastern Europe and whether the number of PT jobs grows or decreases with the declining economy. Since the motivations of employees for part-time work differ substantially between women and men and different age groups, we expect a different impact across these groups. The paper aims to identify the effect of the business cycle on aggregate development of part-time employment as well as the distinct impact on particular

for the opportunity to work fewer hours and use flexible working-time arrangements. For a detailed discussion on this topic see e.g. Wolf (2002).

${ }^{5}$ These disadvantages (so called "part-time penalty") tend to be lower in countries where parttime employment is more popular (OECD, 2010).

${ }^{6}$ For details about the effect of other factors of influence see for instance Buddelmeyer et al. (2008) or Fialová (2017). 
demographic groups of workers by exploiting both cross-sectional and time series variations.

The key result reveals that contrary to the West, the business cycle development exerts a significant negative effect on the part-time employment rate in Eastern Europe. When the economy operates below its potential, part-time employment tends to grow more than full-time employment. This finding is consistent with the labour demand effect and reflects the pursuit of flexibility by firms and adjustment in composition of employment to changing economic conditions. The countercyclical effect is even stronger for involuntary part-time employment. Separate analyses for individual demographic groups of workers reveal a significant negative effect of the business cycle on part-time employment of older workers and male prime-age workers in Eastern Europe. In contrast, the effect is insignificant for young workers and unclear for prime-age women.

The article is organized in the following way. The second section describes the main determinants of PT employment with a focus on the effect of the economic cycle, as well as the motivations of individuals/firms to accept/offer PT jobs. In the next section we sketch the development of PT employment in Europe and compare the East and the West. The fourth section describes the methodology and the data. The fifth section summarizes the key findings of our analysis. The last section concludes and discusses limitations of our research.

\section{Determinants of part-time employment and the effect of business cycle}

Recent literature indicates that since late 1980s the growth in PT employment can be mostly attributed to labour supply factors (for a summary see OECD, 2010). Eurofound (2007) points out that wishes of employees alone or in combination with business needs were often viewed as a primary reason for introducing PT work in companies. Many studies underline the importance of factors on the part of both demand and supply (Abhayaratna et al., 2008, Allaart and Bellmann, 2007, Euwals and Hogerbrugge, 2006, or Tilly, 1991).

From the point of view of labour supply, the development of PT employment is a result of the complex interplay of factors, especially of household division of labour in relation to the institutional background and of labour market conditions (Fagan and O'Reilly, 1998). Significant differences in motivation to work PT exist between women and men of different age. ${ }^{7}$ For women, human capital and work orientations theories explain the effect of differences in women's market resources on their labour supply, which is highly affected by the two main drives for PT employment: motherhood and caring responsibilities. On the contrary, most male part-timers are young labour market entrants or students or, on the opposite side of the age spectrum, older and retired workers. While for men, PT employment usually occurs at the time of labour market entry or exit, female PT employment is more evenly distributed across age groups and is

\footnotetext{
${ }^{7}$ Choosing to work part-time is driven by reasons similar to those for inactivity: studying for the youth, caring responsibilities for prime-age women and retirement and health problems for older workers (OECD, 2010).
} 
a more stable labour market state than for men (Delsen, 1998; Fagan et al., 1995; Blank, 1994).

From the labour demand perspective, PT employment is usually explained under the concept of dual or segmented labour markets (for a detailed discussion on this topic see e.g. Fagan and O'Reilly, 1998). From this point of view, PT job represents a source of cheaper labour to firms and it is perceived as marginalised, secondary form of work. Flexibility is usually cited as the main advantage of PT work for employers. It allows firms to more easily match labour input with the business cycle development. Thanks to PT workers, the employer may profit from increased productivity, the opportunity to cover unsocial hours and short shifts and also cost advantages resulting from lower hourly wage and premia (Smith et al., 1998, Wolf, 2002). The utilisation of PT work also differs across economic sectors; it is widely used in more labour-intensive sectors, such as the trade and the service sector, as it provides a direct link to an increase in productivity (OECD, 2010).

Part-time employment is affected by business cycle developments in the short to medium run. Empirical research on the topic shows that PT employment (relative to full-time employment) tends to decline during economic highs and vice versa and the relationship works through several different channels (Delsen, 1998; OECD, 1999; Buddelmeyer et al., 2008).

As far as labour demand is concerned, two effects may be identified, both of them acting counter-cyclically. The first is connected with the sectorial structure of PT employment. During downturns, sectors mostly employing PT workers, such as services or trade, are usually affected later than other sectors, such as industry or construction. Compared to full-time employment, PT employment is thus relatively less sensitive to the economic cycle movements (Lester, 1999). The second effect comprises changes within sectors. In downturns, employers may tend to reduce working hours to avoid dismissals and stop hiring new full-timers; consequently, in an upswing, part-timers may switch to full-time positions (Delsen, 1998).

Also concerning labour supply several effects may be recognized. Firstly, the labour market slack and economic hardship boosts the number of secondary earners, i.e. those more apt to accept PT work, who enter the labour market to bolster the household income. This "additional worker effect" acts counter-cyclically (Buddelmeyer et al., 2008; Layard et al., 1980). Secondly, unemployed people may be more willing to accept a PT job and workers may be more willing to involuntarily cut back on working hours during a labour market downturn (Tilly, 1991, Buddelmeyer et al., 2008). This effect is usually referred to as "involuntary part-time effect". Thirdly, the decreasing amount of free labour force during expansions may push firms to hire workers who prefer PT, which may increase voluntary PT employment during economic highs (Tilly, 1991). Lastly, labour market slacks may reduce supply of labour, especially female part-timers, through the so-called "discouraged worker effect", which represents a pro-cyclical effect (Delsen, 1998; Darby et al., 2001). As follows from the above-mentioned, the direction of the overall effect depends on the relative weights of each of the effects. Generally, the pro-cyclical effects are supposed to be weak (Buddelmeyer et al., 2008).

Recent literature indicates that involuntary PT employment is more sensitive to the business cycle development than voluntary PT employment. This may be explained by 
the domination of labour demand factors (Buddelmeyer et al., 2008, Brender and Gallo, 2008, Partridge, 2003). Using the pooled cross-sectional US data Partridge (2003) established that the share of voluntary PT employment tends to be pro-cyclical, as opposed to the involuntary PT employment rate, which moves in the same direction as the unemployment rate, suggesting that these two labour market states share some common features. However, the author shows that the rate of involuntary PT employment tends to be less sensitive to the job growth than the unemployment rate, indicating that involuntary PT workers can face even greater difficulties in finding fulltime positions than unemployed workers. These results suggest that while the development of voluntary PT employment is mostly determined by labour supply, involuntary PT employment is more significantly driven by labour demand.

\section{Development and main characteristics of part-time employment in Europe}

PT employment in the West and in the East differed substantially both in terms of its level and developments in time. In Eastern Europe PT employment is a less frequent form of employment and the part-time employment rate (PTR), i.e. the share of parttimers on total employment, reached the average of $6.9 \%$ in 2013 (see Figure 1). ${ }^{8}$ In only two out of the thirteen countries (in Malta and Cyprus), the level of the PTR crossed $10 \%$ in 2013; however, mostly it remained between 5 and $10 \%$ and in Slovakia and Bulgaria below 5\%. ${ }^{9}$ In contrast, the group of Western European countries featured the average PTR of $23.1 \%$ in 2013.

The average PTR in Europe has been on a rise since late 1990s, and the pace of growth slowed down only during the economic downturn of 2008-2009. Also here we see substantial differences between the two examined groups of states. In the West the development of the PTR was more stable: it has been steadily increasing without any larger ups or downs. In contrast, the dynamics of PT employment fluctuated in majority of the Eastern European countries and only Malta, Cyprus, Slovakia, the Czech Republic and Hungary exhibited a clearly upward trend (see Annex 1.1 and 1.2).

The average annual growth rate of the PTR was $+3.1 \%$ in the West in 1998-2007 (Annex 2.1 and 2.2). The respective figure for the East showed an average slight decline of $-0.5 \%$. Consequently, years 2009 and 2010 meant a significant rise in the PTR in the majority of the Eastern European countries, which turned into a stronger average annual increase of $+4.8 \%$ between 2008 and 2013. In contrast, the Western European states held on to their slower, yet stable growth: the economic hardship brought along deceleration of the average annual growth in the West to $+2.6 \%$ between 2008 and 2013. Apparently, the global economic recession had a different impact on PT employment in these two groups of countries, with a higher sensitivity to the business cycle development in the East.

\footnotetext{
${ }^{8}$ Unless stated otherwise, the aggregate data concern age group 15-64 years.

${ }^{9}$ The situation in the West and the East is depicted in Annex 1.1 and 1.2.
} 
Figure 1. Total and involuntary part-time employment in Europe as \% of total employment, 2013

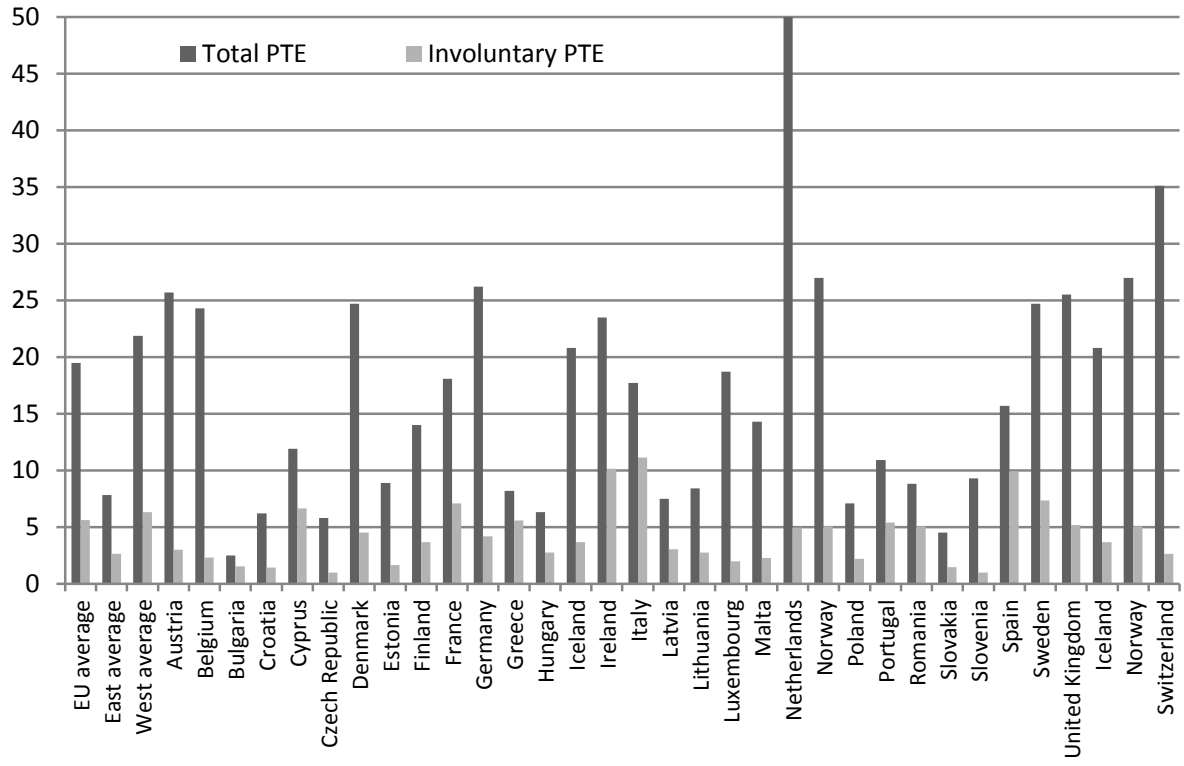

Source: Eurostat

Substantial disparities in the PT employment rates exist between the genders and between different age groups. In Europe the highest average incidence of PT employment was among young people aged 15-24 (almost one third in 2013). PT workers aged 25-64 contributed to total employment with around $20 \%$. In every age group, women tended to choose PT employment more often than men. The difference was not as pronounced for young people aged 15-24 (women 40.2\%, men 24.7\%). However, for prime-age workers (25-49), the difference was more than four times as high: $30.2 \%$ of women against $6.5 \%$ of men. The majority of all PT workers were prime-age women in many countries. The share of prime-age women tended to be higher in countries where PT employment is more common. ${ }^{10}$ The variation in agegender patterns between the East and the West in categories 15-24, 50-64 and 25-49 men showed a roughly similar pattern, with the East recording on average about half of the average values of the West. However, women in the East worked PT relatively less often compared to the West: the average PTR was only $7.5 \%$ in the East, compared to $36.9 \%$ in the West in 2013.

\footnotetext{
${ }^{10}$ The correlation is statistically significant and positive at 0.40 in EU. In general, the more people work part-time in a country, the larger the disparities between part-time rates of men and women.
} 
The majority of PT employment is the result of a voluntary decision of workers. ${ }^{11}$ In 2013, the share of involuntary PT employment on total PT employment in the West was substantially lower than in the East and reached the average of $27.3 \%$ and $37.8 \%$, respectively. In this perspective, large disparities exist between individual countries within the two country groupings, see Figure 1. In general, countries with higher PT employment tend to record relatively lower involuntary PT employment.

The share of involuntary PT employees was lower for older workers aged 50-64: almost $25 \%$ both in the East and the West in 2013. In all other age groups, the figures of the Eastern European countries exceed those of the Western European countries. Young and prime-age female involuntary PT workers accounted for almost $40 \%$ of all part-timers in their category in the East (less than $30 \%$ in the West), and the respective share of prime-age men reached almost $60 \%$ in the East (less than $50 \%$ in the West). ${ }^{12}$

\section{Methodology and data}

Our methodology mainly follows the approach established by Buddelmeyer et al. (2008), which we extend on the Eastern European countries. To exploit both inter- and intra- regional variation, we pool data from the European countries of our concern. Our sample consists of data for twenty-eight European countries in the period 1998-2013. ${ }^{13}$ Separate estimations were run for the Eastern European and the Western European countries and the significance of the differences was further analysed by the standard Chow tests.

Part-time employment rate follows a positive trend in all Western European countries and in several Eastern European countries and the presence of a unit root was confirmed for most of the countries using the Phillips-Perron and Augmented Dickey-Fuller (ADF) tests. To address the issue of non-stationarity, we use the annual change in the PT employment rate as the dependent variable $(\Delta \mathrm{PTR})$. To analyse the effect of the business cycle on the PTR we use the following fixed-effects model specification:

$$
\Delta P T R_{i t}=\alpha_{i}+\beta B C_{i t}+\varepsilon_{i t}
$$

where $\alpha_{i}$ are country dummies and $B C$ denotes the measure of the cyclical position of the economy. This model breaks down the development of the PTR into a cyclical

\footnotetext{
${ }^{11}$ Yet, voluntariness of the remaining part of the PT workers may be questionable. The choice of PT employment may be influenced by external constraints that vary over life cycle and that are temporary in nature (inability to work longer hours given by study or caring responsibilities, disability, illness etc.) or determined by employment status of other household members.

${ }^{12}$ However, when expressed as a share of total employment, involuntary part-timers show lower shares in the East than in the West for every group with the exception of prime-age men due to the relatively low part-time rates in the East.

${ }^{13}$ As some of the variables employed in the following estimations were not available for all the countries and years, several model specifications had to rely on a limited sample regarding the number of countries or years covered. The exact definition of country sample is given below the tables presenting the results of our estimations.
} 
component and a linear country-specific trend, which corresponds with the countryspecific intercept.

To proxy the country's position in the business cycle, we use (i) estimates of the output gap and (ii) the real GDP growth. Output gap refers to the difference between the actual and the potential gross domestic product as a per cent of the potential GDP. The potential GDP is a result of model-based estimates which use the production function method, and it corresponds to the productive capacity of the economy. The output gap is considered a better measure of the cyclical position, as the real GDP growth also reflects the differences in development of potential output between countries. Nevertheless, taking into account the model-based nature of the output gap estimates, the real GDP growth is used for a robustness check. ${ }^{14}$

In this specification, lagged independent variables are also included. Number of lags to be covered was tested by a Wald test, the results of which indicate that two periods lags are sufficient. We also analysed potential asymmetry in business cycle effects that was investigated by Buddelmeyer et al. (2008), and used the output gap interacted with dummy variables, which determine whether the output gap is positive or negative.

The part time employment rate (PTR) shows the share of part-timers in a given demographic group of employees. This indicator comes from the Eurostat Labour Force Survey and is self-reported by individuals. ${ }^{15}$ Involuntary PT employment is a selfreported state of respondents for whom PT job is only an involuntary substitute for a full-time position. The real annual GDP growth comes from the Eurostat database; the output gap indicator is the model estimate of the European Commission (DG-ECFINAMECO database) based on the production function method.

\section{Results}

The aggregated results of our estimations are presented in Table 1 and details are offered in Annexes 3-5. The results point to significant differences in the effect of the business cycle on part-time employment rates in the East and the West.

In the East, the output gap exerts a significant negative impact on an increase in the PTR: when the economy operates below its potential, the PTR tends to grow. This means that PT employment grows to a larger extent than full-time employment. This result is consistent with the labour demand effect on the PTR described in previous sections and reflects the pursuit of flexibility and changes in composition of employment across sectors. Furthermore, the significant negative effect of the business cycle on the involuntary PTR is consistent with the involuntary part-time effect. The main channel of influence is the concurrent output gap, meaning that a larger part of the

\footnotetext{
${ }^{14}$ Our results are partly limited by utilisation of annual data. Quarterly data would be more appropriate, as they offer more detailed information on the business cycle development. However, data on output gap (and other variables utilised in subsequent analysis) is available in annual frequency only.

${ }^{15}$ Except for the Netherlands, Iceland and Norway, where PT is determined if the usual hours are fewer than 35 hours and full-time if the usual hours are 35 hours or more.
} 
effect occurs within the same year, as the lagged output gap values generally do not prove significant in our analyses. ${ }^{16}$ However, the magnitude of the business cycle effect on the PTR is rather limited: an increase in output gap of one percentage point tends to be associated with a decline in the PTR of approximately 0.09 percentage points. ${ }^{17}$ Moreover, the counter-cyclical pattern is stronger during an economic downturn than during an economic boom (column 3 of Annex 3): This again indicates that PT employment is used by employers as a device to cope with increasing uncertainty of economic conditions during downturns.

Table 1. Business cycle effect on part-time employment rate

\begin{tabular}{|c|c|c|c|c|c|c|c|c|c|}
\hline & \multicolumn{4}{|c|}{ Output gap } & \multicolumn{2}{|c|}{ Output gap $(-1)$} & \multicolumn{2}{|c|}{ Output gap (-2) } & \multirow{2}{*}{$\begin{array}{l}\text { Chow } \\
\text { test } p \text { - } \\
\text { value }\end{array}$} \\
\hline & East & & West & & East & West & East & West & \\
\hline 15-64 total & -0.091 & $* * *$ & -0.050 & $*$ & 0.026 & 0.014 & 0.046 & 0.013 & 0.0427 \\
\hline $15-24$ total & -0.057 & & -0.384 & $* * *$ & -0.090 & 0.138 & 0.187 & 0.080 & 0.0092 \\
\hline 50-64 total & -0.094 & $* * *$ & 0.032 & & 0.006 & -0.035 & 0.049 & 0.025 & 0.0018 \\
\hline 25-49 females & -0.092 & $* *$ & 0.009 & & 0.021 & -0.028 & 0.037 & -0.006 & 0.1366 \\
\hline 25-49 males & -0.109 & $* * *$ & -0.084 & $* * *$ & $0.074 \quad * * *$ & 0.027 & 0.014 & -0.008 & 0.0014 \\
\hline \multicolumn{10}{|c|}{ Dependent variable : annual change in involuntary part-time employment rate } \\
\hline & \multicolumn{4}{|c|}{ Output gap } & \multicolumn{2}{|c|}{ Output gap $(-1)$} & \multicolumn{2}{|c|}{ Output gap (-2) } & \\
\hline & East & & West & & East & West & East & West & value \\
\hline 15-64 total & -0.071 & $* * *$ & -0.093 & $* * *$ & 0.023 & 0.009 & 0.020 & -0.003 & 0.0443 \\
\hline $15-24$ total & -0.102 & $* *$ & -0.247 & $* * *$ & 0.005 & -0.031 & 0.070 & $0.123 * * *$ & 0.0398 \\
\hline 50-64 total & -0.078 & $* *$ & -0.067 & $* *$ & 0.038 & 0.009 & -0.004 & \begin{tabular}{|l}
-0.018 \\
\end{tabular} & 0.2519 \\
\hline $25-49$ females & -0.071 & $* * *$ & -0.114 & $* * *$ & 0.007 & 0.011 & $0.028 \quad * * *$ & -0.022 & 0.0067 \\
\hline 25-49 males & -0.075 & $* *$ & -0.075 & $* * *$ & 0.041 & -0.004 & 0.016 & 0.008 & 0.0711 \\
\hline
\end{tabular}

Source: Eurostat LFS, European Commission, own calculations

Note: ***/**/* statistically significant at 1\%/5\%/10\% level. Coefficients obtained by fixed effects estimations. Number of observations - East: 150, West: 240. Time period - East: 2002-2013, West: 1998-2013. Iceland, Norway and Switzerland are excluded from the analysis due to missing data.

\footnotetext{
${ }^{16}$ The robustness of our result was confirmed by both estimations based on the use of instrumental variables to account for possible endogeneity of the output gap variable (column 4 of Annex 3) and the estimation based on the real GDP growth variable instead of the output gap (column 2 of Annex 3). In both cases, the effect of business cycle is weaker; the GDP growth tends to influence the PTR with a delay.

${ }^{17}$ For instance, in period 2004-2008, which was characterized by continuously positive output gaps in most Eastern European countries, the PTR declined on average by mere 0.4 percentage points, although according to our computations the estimated effect of observed output gaps should be -1.7 percentage points. This indicates that other factors of influence play an important role in determining the development of part-time employment as well.
} 
On the other hand, the effect of business cycle on the total PTR is weaker and insignificant in the West, regardless of whether approximated by the output gap, the GDP growth or instrumented (see Annex 3). ${ }^{18}$ This result is consistent with research by Fialová (2017), but does not support the findings of Buddelmeyer et al. (2008), who used a similar method and reported a significant negative effect for western European countries (EU-15) in 1984-2001. We tested the robustness of our estimates using output gaps published in the OECD Economic Outlook database instead of the estimates published by the European Commission. However, this led to very similar results. ${ }^{19}$ The disparity between our and Buddelmeyer's results may be explained by a change in patterns of relationship between the business cycle and the PTR in time. In contrast to insignificance of the business cycle effect on the total PTR, the output gap shows a strong and highly significant negative effect on the involuntary PTR, even higher than in the East. This indicates that changing economic environment tends to force people into PT employment to a larger extent than to stimulate their own, voluntary workingtime decision.

To test the significance of the reported differences in the effect of the business cycle on the PTR in the East and the West we employ the Chow tests. The results reject the hypothesis of the stability of coefficients between these two groups of countries at the $5 \%$ significance level, both for the total PTR and the involuntary PTR. This confirms that the business cycle affects the development of PT employment to a different extent in the West and the East.

We moved on to analyse the effect of the business cycle on the PTR separately in four different population sub-groups: young workers, older workers, prime-age females and prime-age males. For young workers (Annex 4a), the effect of the output gap on the total PTR in the East is unclear, as coefficients on the output gap are insignificant as confirmed by robustness checks. The situation in the West differs: the output gap shows a strong significant negative effect. The effect of the business cycle on the involuntary PTR in both sets of countries is significantly negative, and the magnitude is once again higher in the West. The results of the Chow test reject the hypothesis of stability of the coefficients between these two groups of countries at the $5 \%$ significance level, both for the total PTR and the involuntary PTR.

Our next target was older workers (Annex 4b). Here, the results indicate a significant negative effect of the output gap on the PTR in the East. In the West, the PTR of older

\footnotetext{
${ }^{18}$ The causality between PT employment and the output gap might be questioned as employment directly affects economic growth through household disposable income and consumption. In order to test the robustness of our results to this possible endogeneity, Granger's predictive causality test was performed (see Annex 6). The test, which included up to three lags, rejected the null hypothesis of no Granger causality for all the specifications, with the exception of 15-64 and 50-64 age groups in the West and prime-age females in both regions (see also below). This is also reflected in insignificant coefficients for these groups which resulted from our estimation.

Moreover, we instrument output gap by the growth rate of fixed capital investment to further support the idea that the direction of the causality in the applied regression models is correct. No significant alteration of the results occurred.

${ }^{19}$ Results are available from the author upon request.
} 
workers seem to be driven by other factors, as none of the business cycle proxies seem to exert a significant effect here. Also the result of the Chow test indicates significant differences in the business cycle effect on the PTR in the two country groupings. In contrast, the involuntary PTR shows similar patterns of the business cycle determination in both groups, including the magnitude of the negative effect. The stability of the regression coefficients cannot be rejected in this case.

Our analysis reveals no clear effect of the business cycle on the PTR of prime-age females (Annex 5a). The results indicate that the business cycle exerts a negative effect on the PTR in the East, which is however significant at the 5\% level only, and which was not confirmed by the robustness checks. Furthermore, neither of the business cycle proxies seems to have an effect on the PTR of prime-age females in the West. When examining the Granger causality (results in Annex 6), the coefficients on lagged output gap are jointly insignificant for both the East and the West and also the results of the Chow tests do not indicate significant differences in the effect of the business cycle on the PTR in these two groups of countries. Apparently, labour supply and demand of prime-age women are not sensitive to the business cycle development and are probably influenced by other factors of institutional and structural nature. However, this does not hold for the involuntary PTR, where the business cycle exerts a significant negative effect.

Finally, we consider prime-age males (Annex 5b). Our results indicate a significant negative effect of the business cycle on the PTR, which is robust across different model specifications, in both groups of countries. Although the results of the Chow test for the basic equation point towards a different behaviour of the PTR with respect to the business cycle development in the East and the West, a similar behavioural pattern was not rejected by the results of the Chow test for the instrumented equation. This is confirmed by the estimations for the involuntary PTR that report a comparable significant negative effect of the business cycle in both the East and the West. Our results on the different effect of the business cycle on the male and the female PTR confirm previous research of Kjeldstad and Nymoen (2012) who worked with data from Norway.

\section{Conclusions}

This article examined the phenomenon of part-time (PT) employment. In doing so, two groups of countries were analysed: Eastern and Western Europe. It turned out that PT employment is a widespread form of employment in Western Europe, but scarce in Eastern Europe. Moreover, PT employment in Eastern European countries is often not a choice; rather, for a large share of employees it is an involuntary alternative to a fulltime position. Substantial differences were identified in the demographic structure of part-timers, especially concerning prime-age women. In the East, women aged 25-49 tend to work PT significantly less often than their Western European counterparts and their PT employment is more often an involuntary result of their inability to find a fulltime job.

The results indicate significant differences in the effect of the business cycle on parttime employment rates in the East and the West. In the East, the development of the business cycle has a significant and adverse effect on the PTR, which also reflects in the 
greater volatility of the PTR development. The negative effect is consistent with the pursuit of flexibility in companies and changes in composition of employment across sectors. In contrast, in the West the effect of the business cycle on the total PTR is insignificant; here, the PTR remains on the rise, regardless of what happens in the business. The involuntary PTR is driven by the business cycle to a higher degree than the total PTR, which indicates that the voluntary PTR is more prone to be driven by other factors.

Among the examined demographic groups, further differences were revealed in the effect of the business cycle on the PTR of young workers, where the impact of output gap is significant, negative and relatively strong in the West. On the contrary, in the East, the PTR of young workers seems to be driven by other factors of longer-term nature. An opposite conclusion comes for older workers, whose PT employment is sensitive to the business cycle developments in the East, while the effect in the West is insignificant. Furthermore, our estimations show that the business cycle has an unclear and weak effect on the PTR of prime-age women both in the East and West. Significant negative effect of the business cycle was revealed for the group of prime-age men both in the East and in the West.

Our research shed some light on the factors underlying the low level of PT employment in the Eastern European countries. PT employment of experienced older workers is to a large extent influenced by employers' seek for flexibility during the business cycle, while PT employment of younger workers is not sensitive to economic trends. For both young and older workers, stimulation of PT employment may have some positive consequences: As regards older workers, wider utilisation of PT work may help in reducing the financial burden of ageing population; for the young, PT jobs offer a gate to labour market. They help them gain experience and serve as stepping stones towards full-time employment. For both of these groups, PT employment has a positive relationship to employment rate; it is a viable option to inactivity and may bring about higher labour force utilisation by enabling transitions to and from full-time positions.

Furthermore, PT employment of prime-age men is largely driven by the business cycle trends and is to a large degree involuntary. This is also reflected in the higher volatility of PT employment of prime-age men. Lastly, PT employment of prime-age women is not sensitive to the business cycle development. Although prime-age women account for majority of part-time employment in most of the European countries, their involvement in part-time work is a more stable labour market state driven by other determinants of structural and institutional nature with a long-term effect.

Funding: This work was supported by the Czech Science Foundation under grant "Changing work and job values in the Czech Republic in a comparative perspective" [14-15008S]. The article is based on a broader research project, the results of which were published in Fialová (2016).

Disclosure statement: No potential conflict of interest was reported by the author. 


\section{References}

ABHAYARATNA, J., ANDREWS, L., NUCH, H., PODHURY, T. (2008) Part-time Employment: The Australian Experience. Productivity Commission Staff Working Paper, June, Melbourne.

ALLAART, P., BELLMANN, L. (2007) Reasons for Part-time Work: An Empirical Analysis for Germany and the Netherlands. International Journal of Manpower, 28(7): 557-570.

BLANK, R. M. (1990) Are part-time jobs bad jobs? In: Burtless G. (ed.) A future of lousy jobs. Brookings Institute, Washington, DC

BLANK, R. M. (1994) The dynamics of part-time work. NBER Working Paper, No.4911.

BOOTH, A.L., van OURS, J.C. (2010) Part-time Jobs: What Women Want? IZA Discussion Paper 4686, IZA, Bonn.

BRENDER, A., GALLO, L. (2008) The Response of Voluntary and Involuntary Female Part-time Workers to Changes in Labor-Market Conditions. Bank of Israel Research Department Discussion Paper, No. 2008.08.

BUDDELMEYER, H., MOURRE, G., WARD, M. (2004) Recent Developments in Part-time Work in EU-15 Countries: Trends and Policy. IZA DP No.1415.

BUDDELMEYER, H., MOURRE, G., WARD, M. (2008) Why Do Europeans Work Part-time? A Cross-country Panel Analysis. European Central Bank Working Paper, No. 872, Frankfurt-am-Main.

DARBY, J., HART, R., VECCHI, M. (2001) Labour Force Participation and Business Cycle Fluctuations: A Comparative Analysis of Europe, Japan and the United States. Japan and the World Economy, 13: 113-133. DOI: 10.1016/S0922-1425(00)00049-9

DELSEN, L. (1998) When do men work part-time? in Part-time prospects: an international comparison of part-time work in Europe, North America and the Pacific Rim. Jacqueline O'Reilly and Colette Fagan editors. Routledge. London and New York.

EICHHORST, W., MARX, P. (eds.) (2015), Non-Standard Employment in PostIndustrial Labour Markets: An Occupational Perspective. Edward Elgar Publishing, Cheltenham.

EUROFOUND (2007) Part-time Work in European Companies. European Foundation for the Improvement of Living and Working Conditions, Dublin.

EUROFOUND (2011) Part-time Work in Europe - European Company Survey 2009. European Foundation for the Improvement of Living and Working Conditions, Dublin.

EUWALS, R., HOGERBRUGGE, M. (2006) Explaining the Growth of Part-time Employment: Factors of Supply and Demand. Labour, 20(3): 533-557. DOI: 10.1111/j.1467-9914.2006.00352.x

FAGAN, C., PLANTINGA, J., RUBERY, J. (1995) Does Part-time Work Promote Sex Equality? A Comparative Analysis of the Netherlands and the UK. Discussion Paper FS I 95-203. Berlin: Social Science Research Centre Berlin. 
FAGAN, C., O'REILLY, J. (1998) Conceptualising part-time work - The value of an integrated comparative perspective. in Part-time prospects: an international comparison of part-time work in Europe, North America and the Pacific Rim. Jacqueline O'Reilly and Colette Fagan editors. Routledge. London and New York. FIALOVÁ, K. (2017) Why don't Eastern Europeans Work Part-time? Ekonomický časopis, 65(2): 125-142.

FIALOVÁ, K. (2016) Práce na částečný úvazek v evropských zemích. in Práce, hodnoty a blahobyt: české reálie v evropském kontextu. Jiří Večerník editor. Sociologický ústav AV ČR. Praha. pp. 42-65.

GARIBALDI, P., MAURO, P. (2002) Anatomy of employment growth. Economic Policy, 17(34): 67-113. DOI: $10.1111 / 1468-0327.00084$

KJELDSTAD, R., NYMOEN, E.H. (2012): Underemployment in a gender-segregated labour market. Economic and Industrial Democracy, 33(2): 207-224.

LAYARD, R., BARTON, M., ZABALZA, A. (1980) Married women's participation and hours. Economica, 47(185): 51-72. DOI: $10.2307 / 2553167$

LESTER, A. (1999) Labour demand and the economic cycle. Reserve Bank of Australia Bulletin.

MOURRE, G. (2006) Did the pattern of aggregate employment growth change in the euro area in the late 1990s? Applied Economics, 38(15): 1783-1807. DOI:

$\underline{10.1080 / 00036840500427072}$

OECD (1999) Focus on Part-time work. Employment Outlook. Organization for Economic Cooperation and Development, Paris.

OECD (2010) How Good is Part-time Work? In: OECD Employment Outlook 2010: Moving beyond the Jobs Crisis. Organization for Economic Cooperation and Development, Paris., pp. 211-266.

PARTRIDGE, M. (2003) Part-time Workers and Economic Expansion: Comparing the 1980s and 1990s with US State Data. Papers in Regional Science, 82(1): 51-73. DOI: $10.1007 / \mathrm{s} 101100200120$

RATTI, R.A. (1991) Involuntary part-time employment: Cyclical behavior and trends over 1968-1987. Economics Letters, 35: 461-464. DOI: 10.1016/0165-1765(91)90020$\underline{\mathrm{L}}$

TILLY, Ch. (1991) Reasons for the continuing growth of the part-time employment. Monthly Labor Review, 114(3): 10-18.

WOLF, E. (2002) Lower wage rates for fewer hours? A simultaneous wage-hours model for Germany. Labour Economics, 9(5): 643-663. DOI: 10.1016/S0927$\underline{5371(02) 00055-6}$ 
REVIEW OF ECONOMIC PERSPECTIVES

\section{Annexes}

20

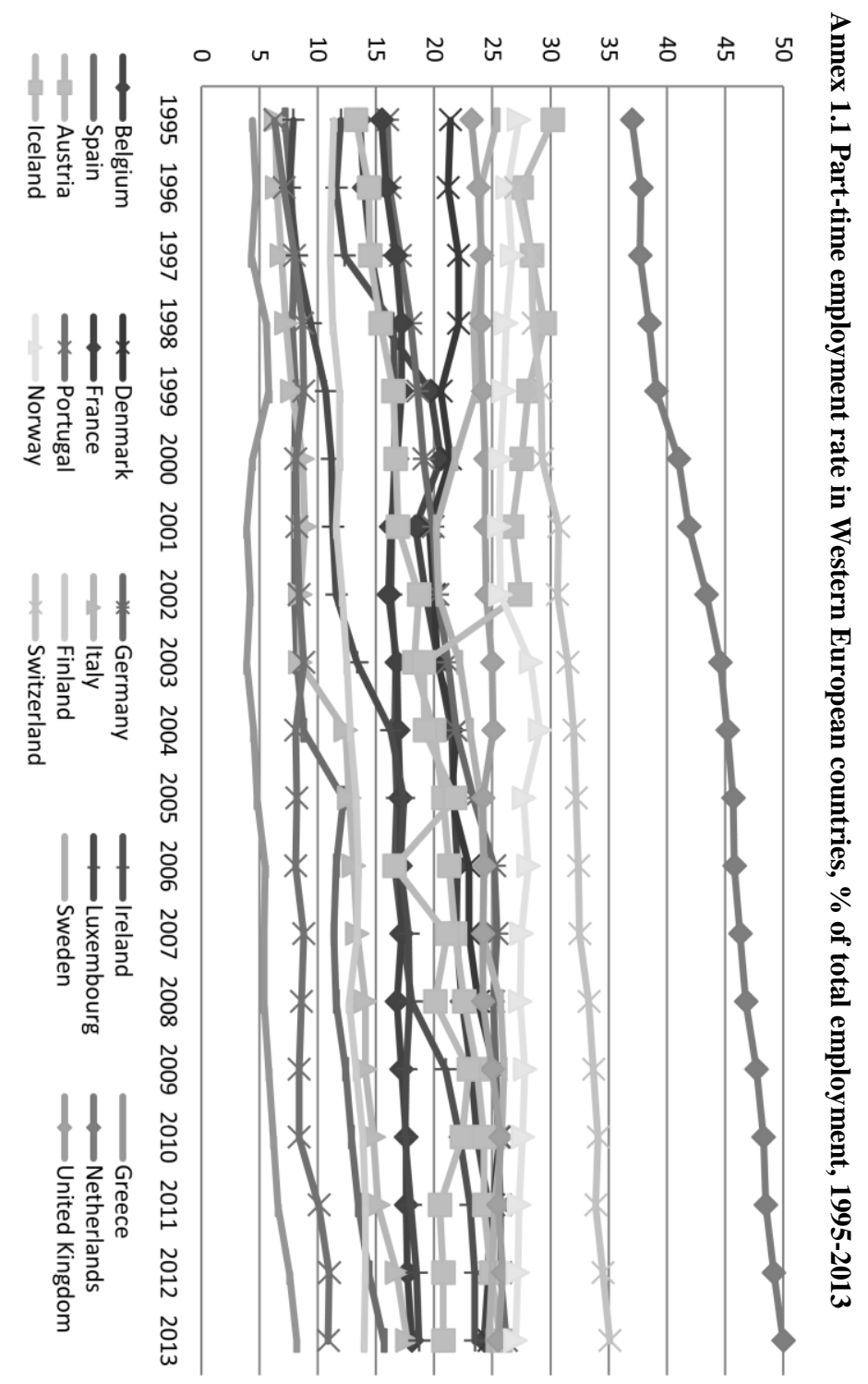




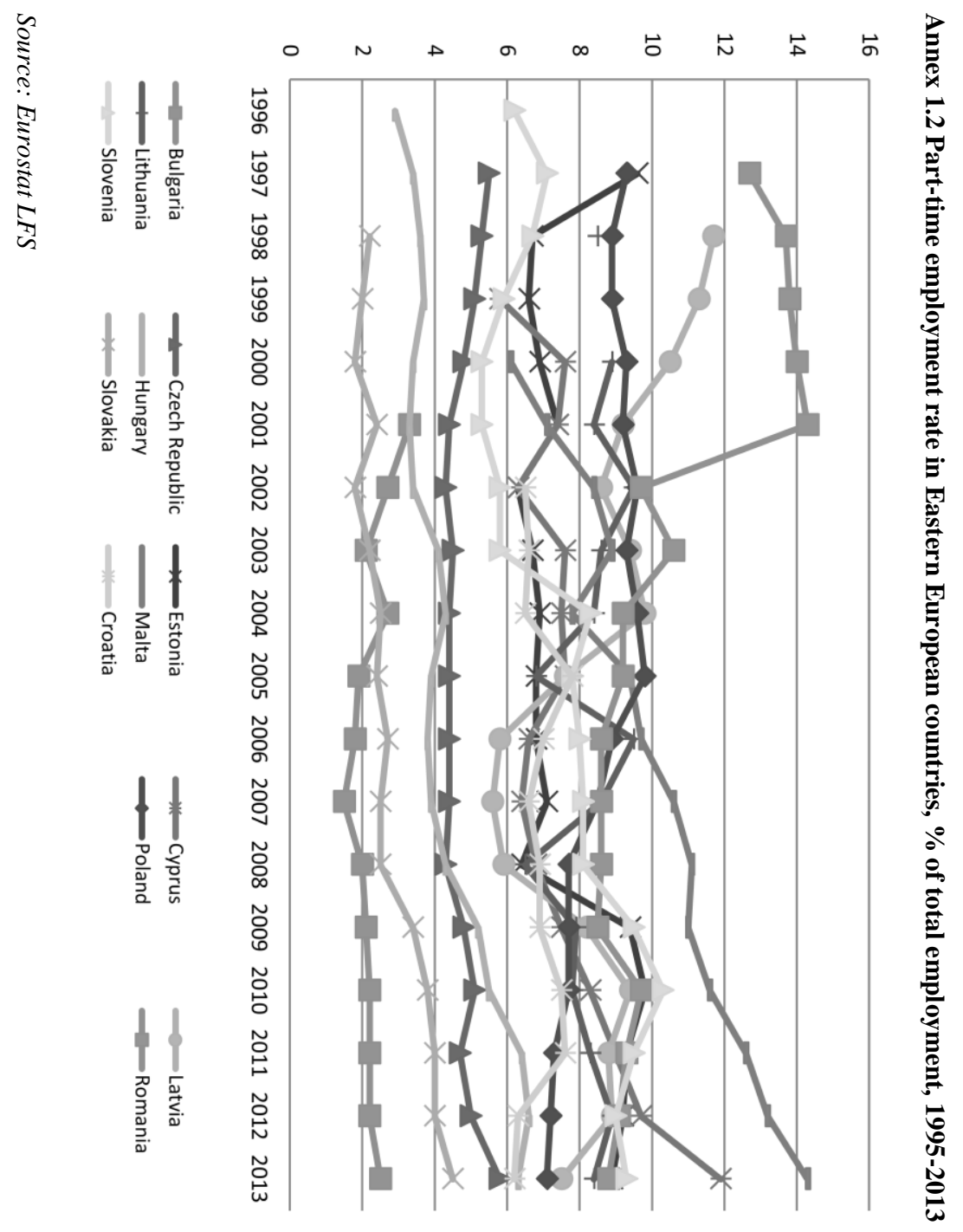




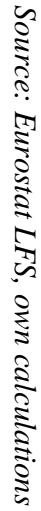

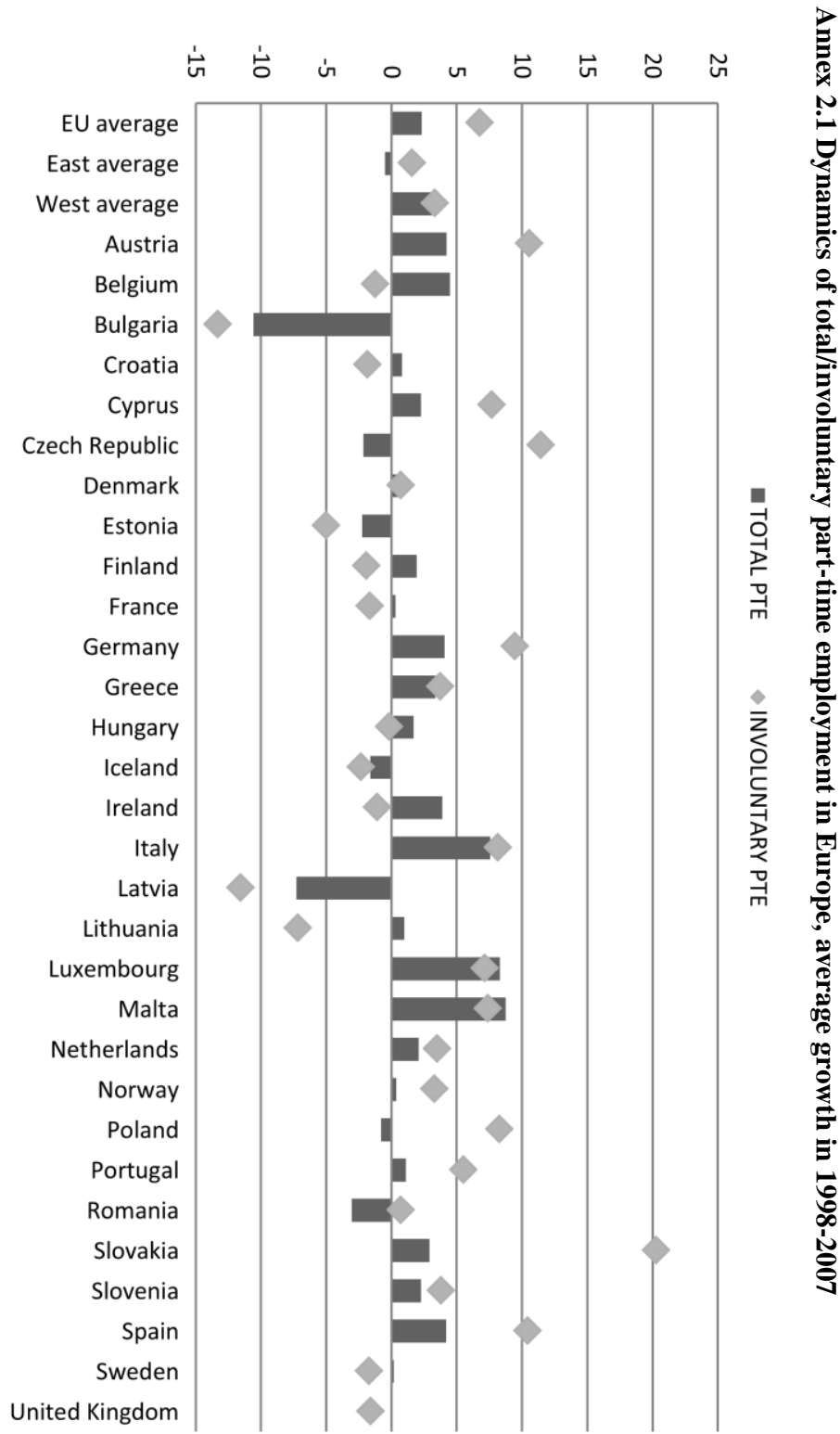




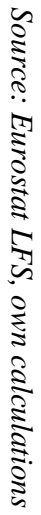

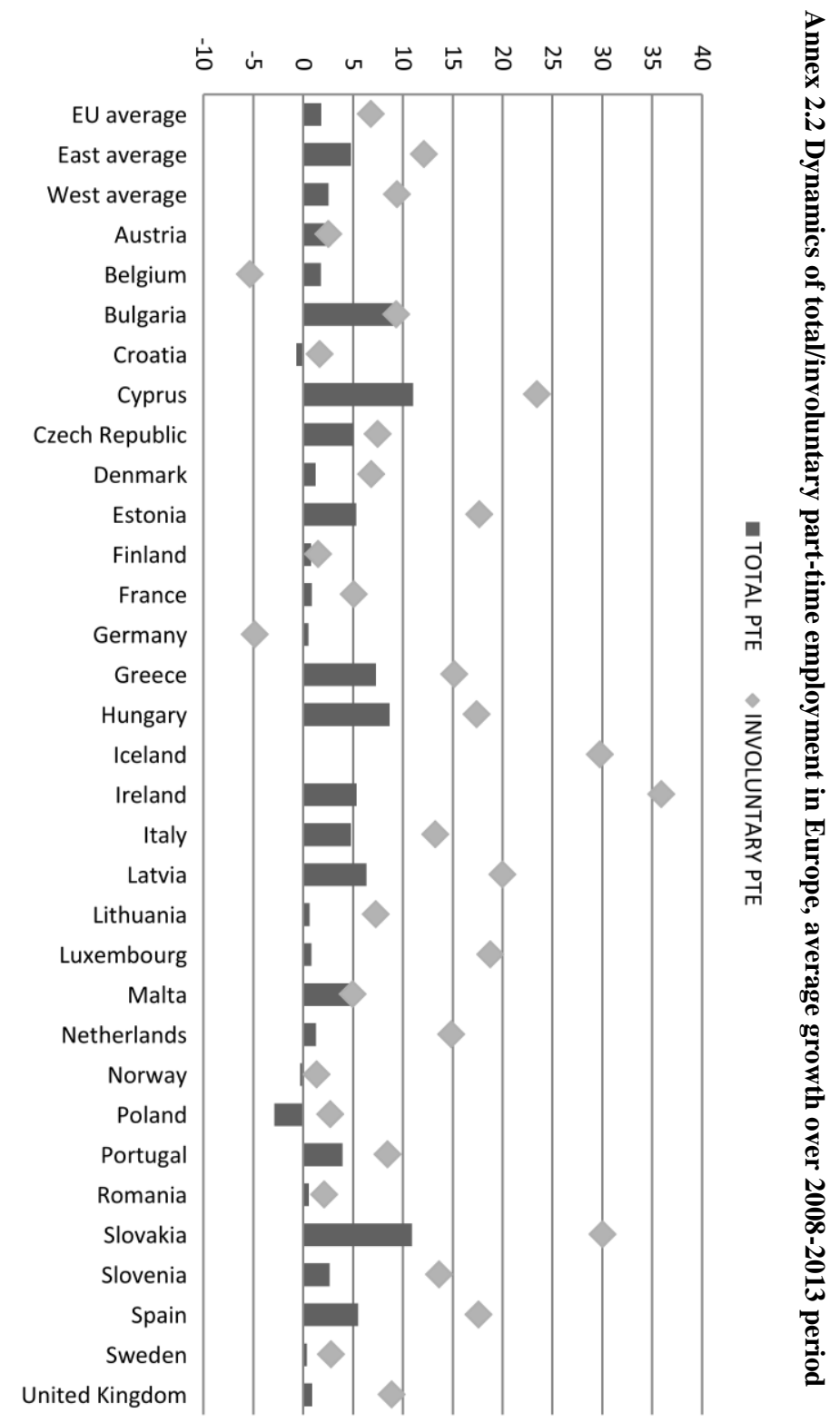




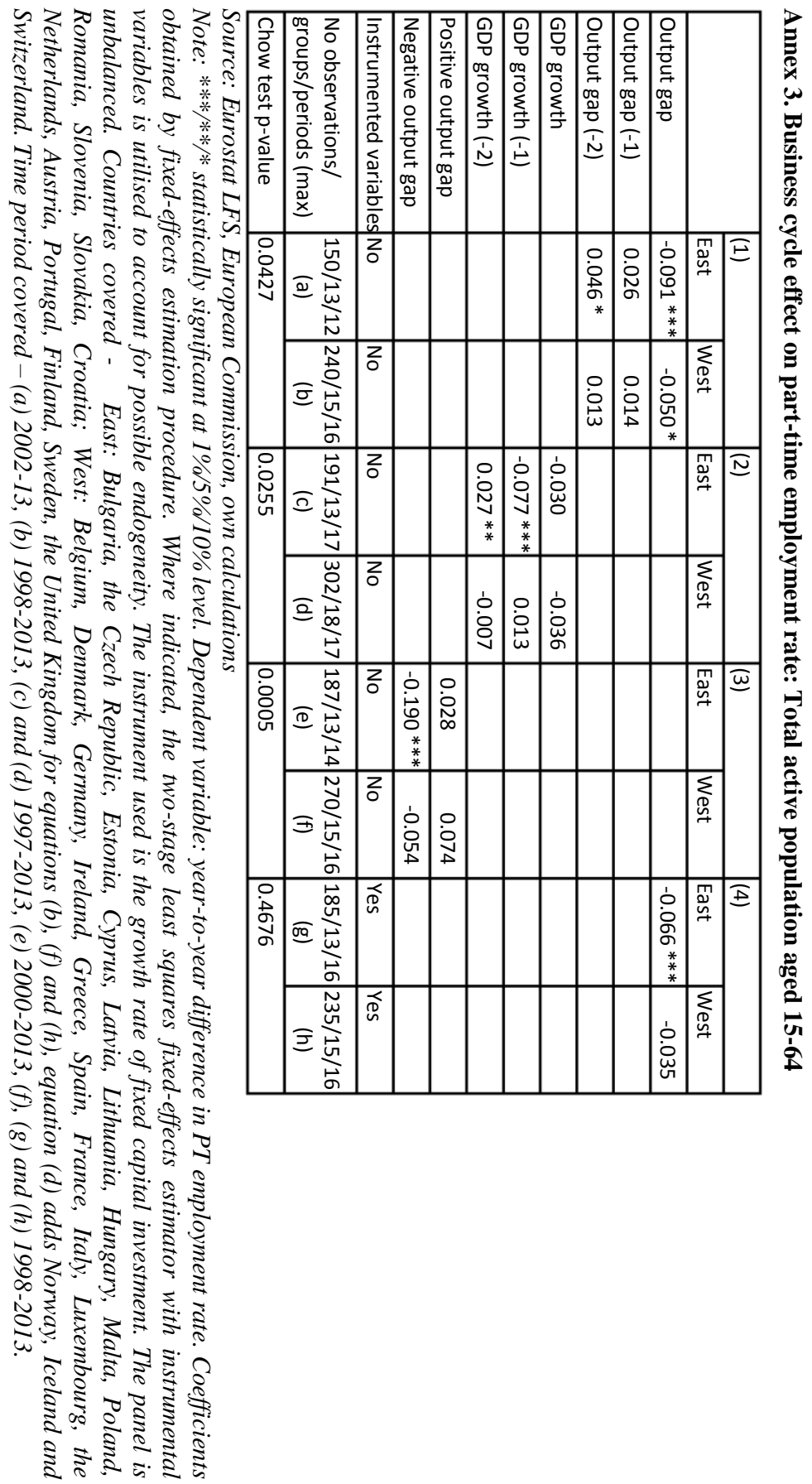




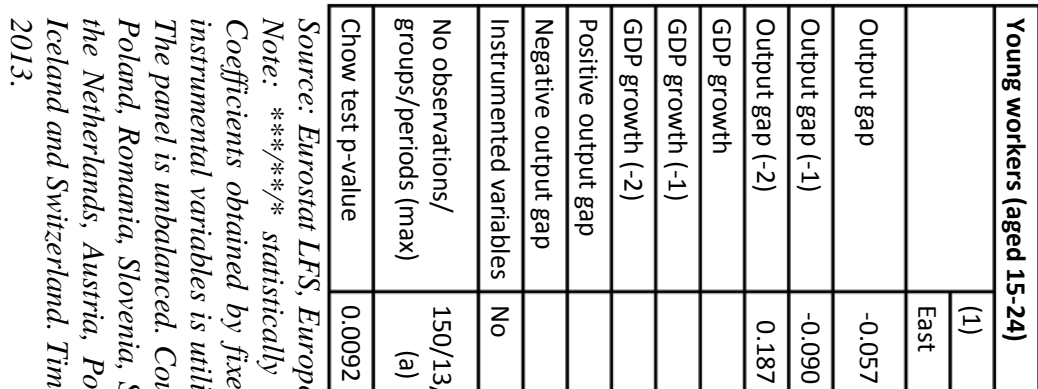

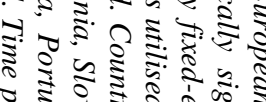

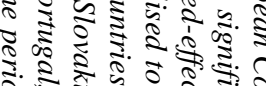

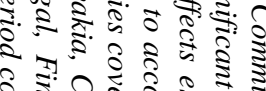

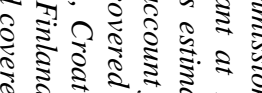

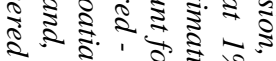

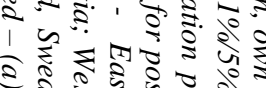

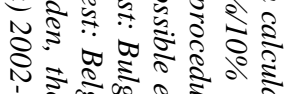

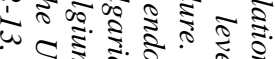

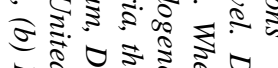

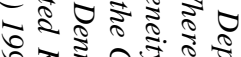

๑

ति:

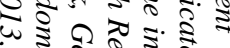

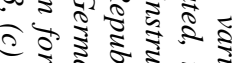

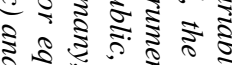

5.

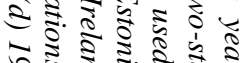

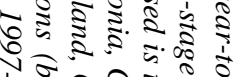

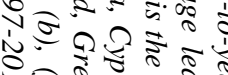

फक

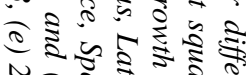

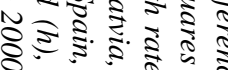

กิร

을

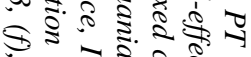

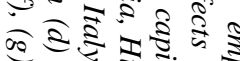

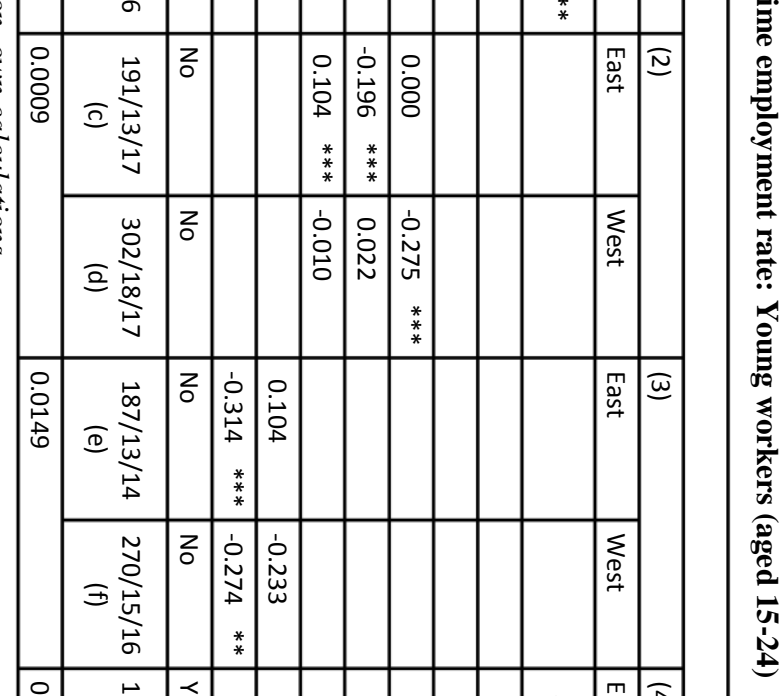

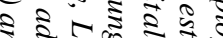

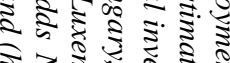

ร)

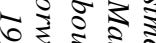

क.

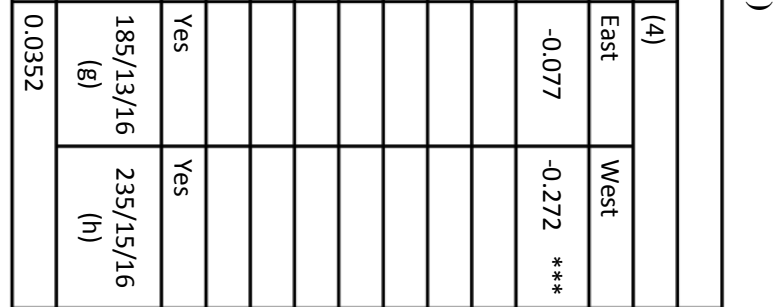




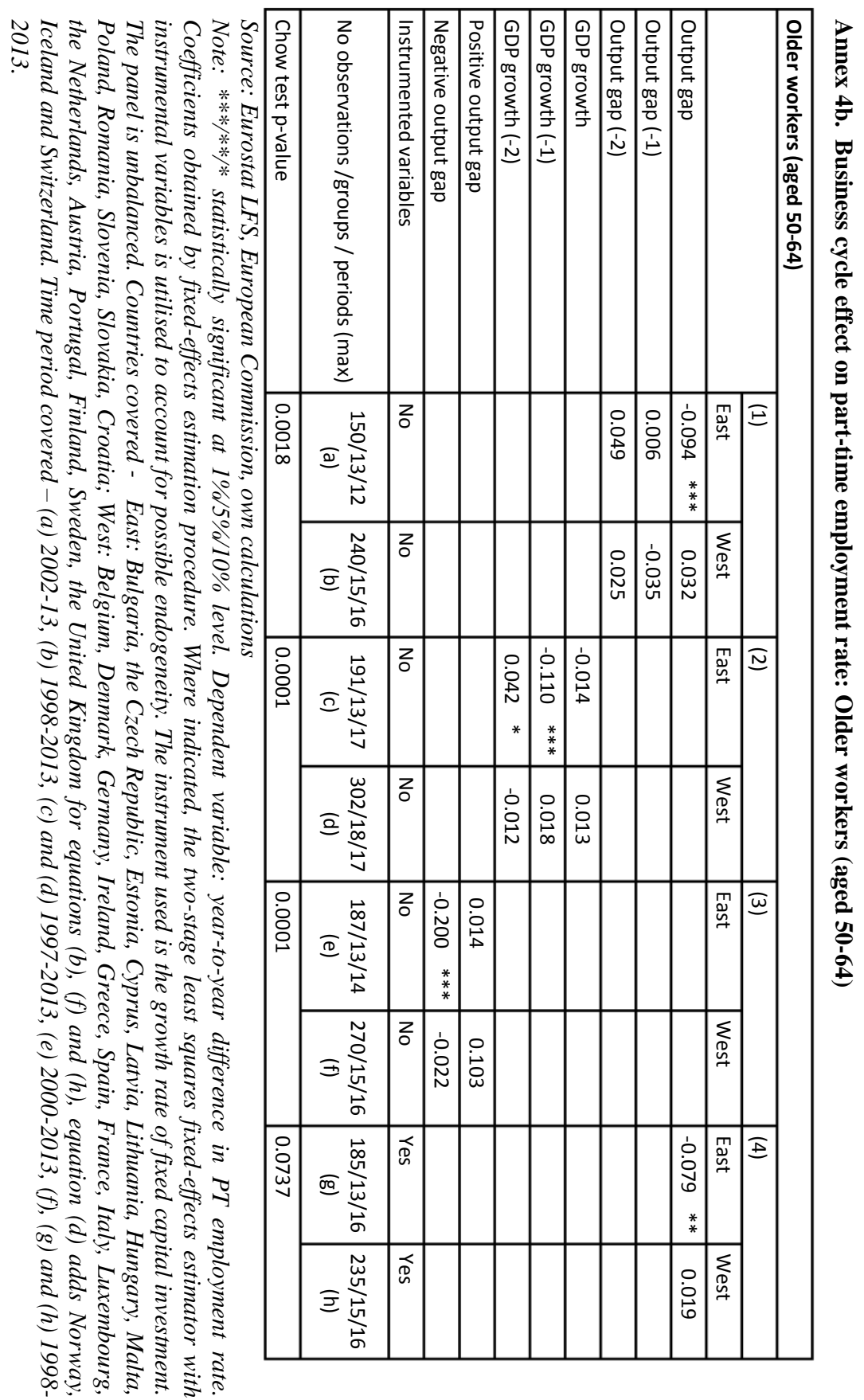




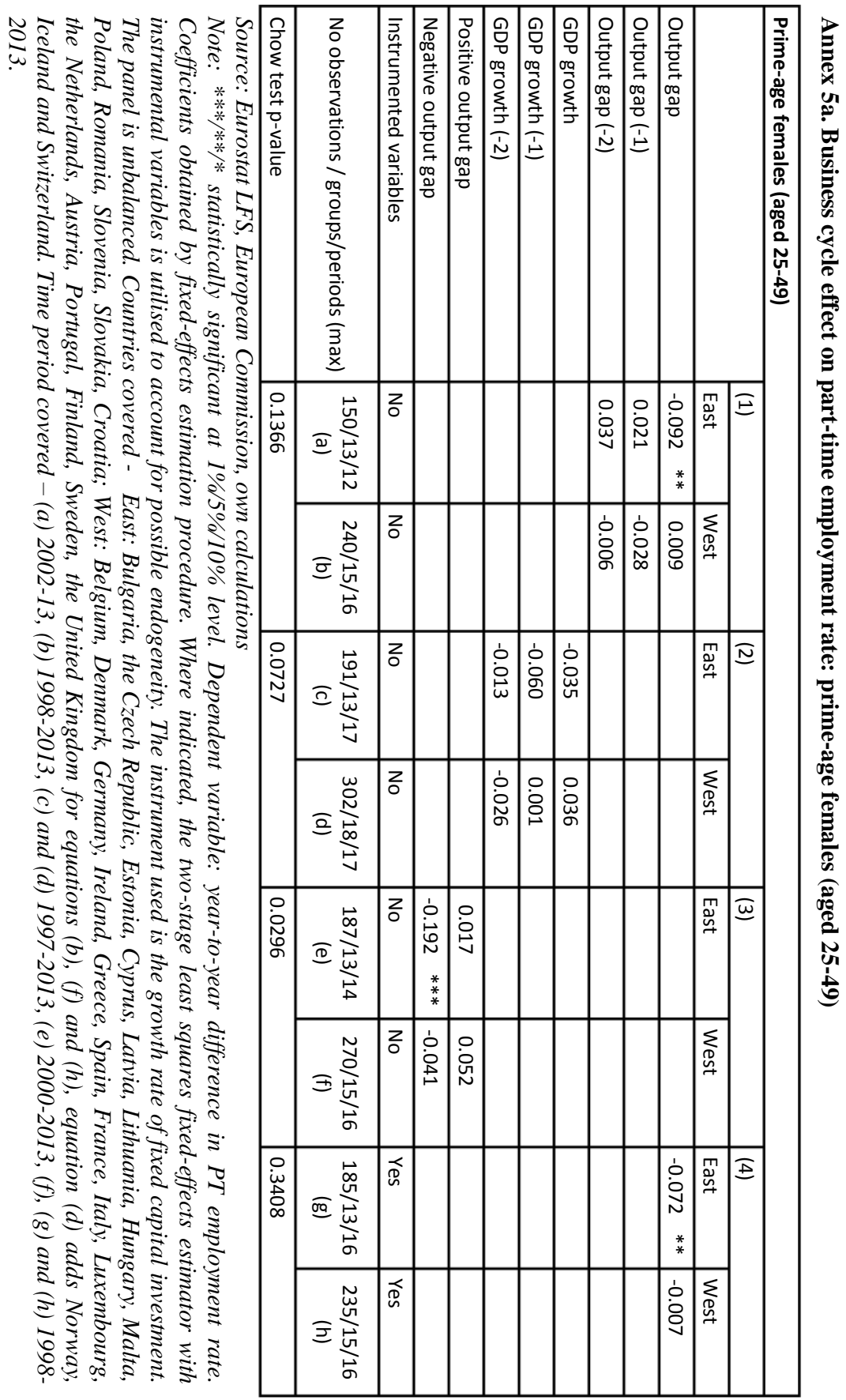




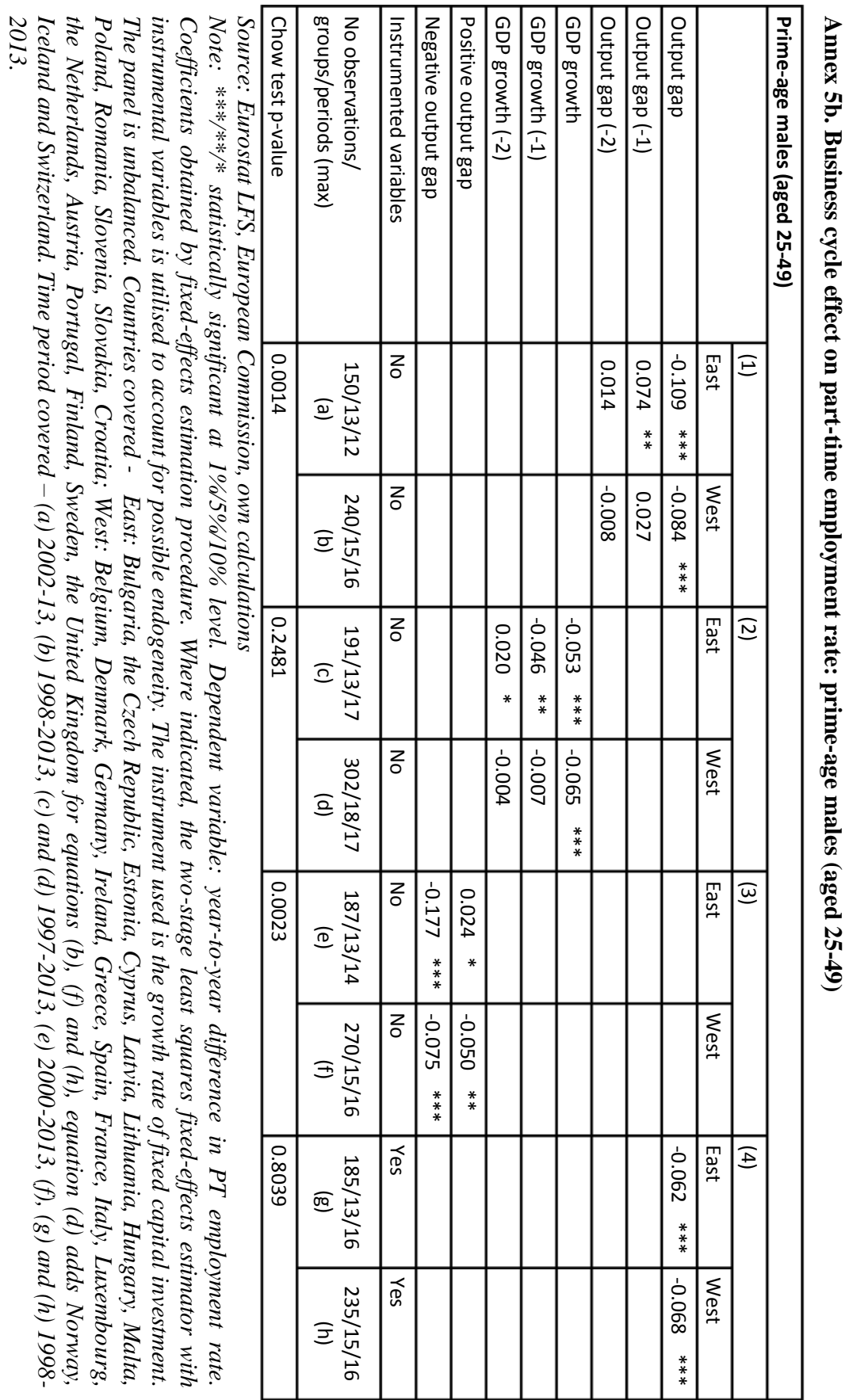




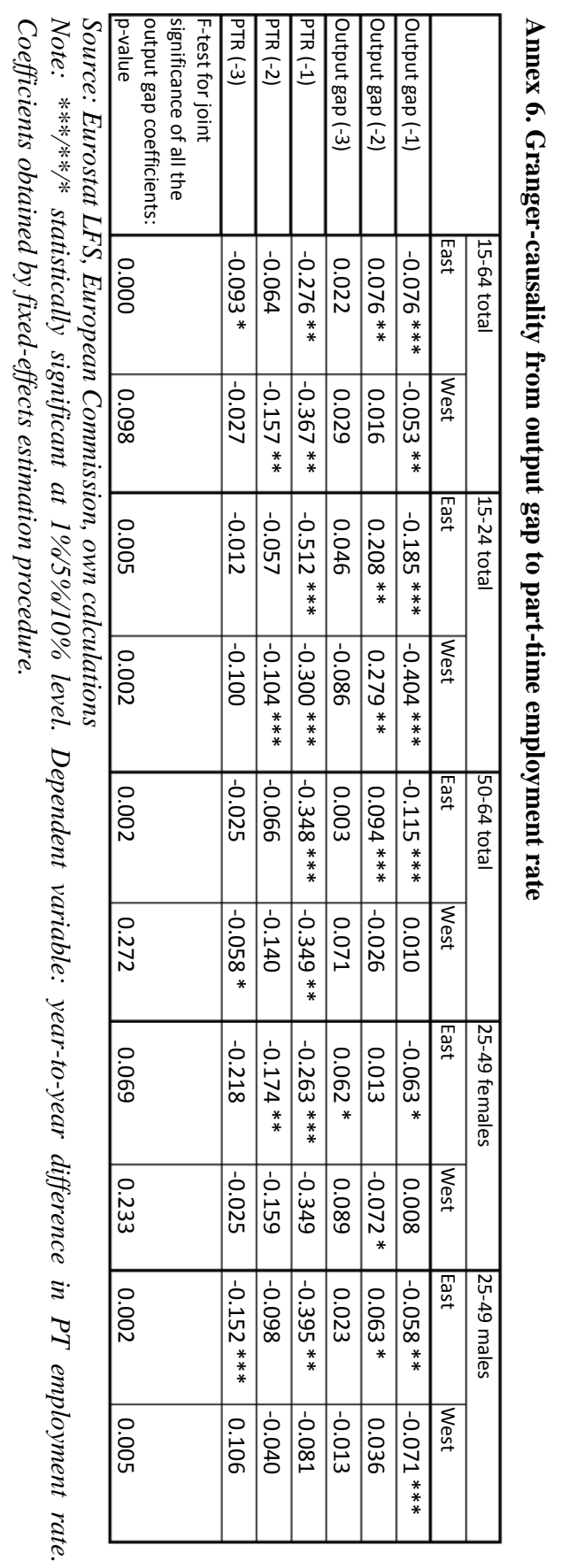

